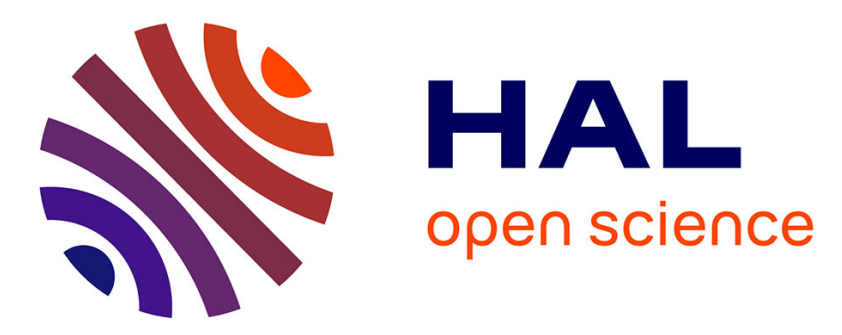

\title{
The influence of solidification rate on structure parameters of aluminium-matrix particulate composites
}

P. Moldovan, C. Alexandru, N. Panait, G. Popescu, D. Condeiu, C. Balescu, G. Ghica

\section{- To cite this version:}

P. Moldovan, C. Alexandru, N. Panait, G. Popescu, D. Condeiu, et al.. The influence of solidification rate on structure parameters of aluminium-matrix particulate composites. Journal de Physique IV Proceedings, 1993, 03 (C7), pp.C7-1811-C7-1816. 10.1051/jp4:19937287 . jpa-00251929

\section{HAL Id: jpa-00251929 \\ https://hal.science/jpa-00251929}

Submitted on 1 Jan 1993

HAL is a multi-disciplinary open access archive for the deposit and dissemination of scientific research documents, whether they are published or not. The documents may come from teaching and research institutions in France or abroad, or from public or private research centers.
L'archive ouverte pluridisciplinaire HAL, est destinée au dépôt et à la diffusion de documents scientifiques de niveau recherche, publiés ou non, émanant des établissements d'enseignement et de recherche français ou étrangers, des laboratoires publics ou privés. 


\title{
The influence of solidification rate on structure parameters of aluminium-matrix particulate composites
}

\author{
P. MOLDOVAN, C. ALEXANDRU, N. PANAIT, G. POPESCU, D. CONDEIU, C. BALESCU and \\ G.V. GHICA*
}

Polytechnique Institute Bucharest, Faculty of Mat. Science and Eng., Spl. Independentei 313, Bucharest 77206, Romania

${ }^{*}$ I.N.T.E.C.-SA Bucharest, Romania

\section{ABSTRACT}

Aluminium alloy-matrix composites with ceramic particulates (Graphite, SiC, Al203, TiC) were synthesised using liquid metallurgy route.

The microstructural characteristics of composites are studied, using scanning electron microscope. Experiments using various cooling rates show that primary cell size is slightly smaller in AlSi $12 \mathrm{CuNiMg}$ ceramic particles composite compared to the base alloy. The microstructure of rapidiy solidified composites revealed a more homogeneous ceramic particles distribution because of the reduced time the composite is in a molten state.

\section{INTRODUCTI ON}

Cast aluminium matrix particulate composites which contain a discontinuous ceramic phase (SiC, Al203, Graphite, TiC) possess many useful properties and represent a class of inexpensive tailor-made materials for a varlety of engineering applications.

In recent years considerable work has been done on the quantification of evolution of solidification microstructures in particle dispersed alloys [1-4].

However the understanding of solidification microstructure formation is difficult due to the unrestricted mobility of the ceramic particles in solidifying melt.

This work was undertaken to determine the role of solidification rate over structure parameters of the aluminium matrix particulate composites.

\section{EXPERIMENTAL}

The composite were prepared by dispersing heat-treated uncoated ceramic particles (average size $30 \ldots 120 \mathrm{um}$ ) i.e., graphite (Gr 5\%vol.), alumina (Al203 5\%vol.), silicon carbide (SiC 15\%vol.) and titanium carbide (TiC 15\%vol.) on the vortex of the aluminium alloy $\mathrm{Al-12.5} \mathrm{Si}-1.3 \mathrm{Cu}-1.8 \mathrm{Ni}-1.5$ $\mathrm{Mg}$, bal.Al) at $1073 \mathrm{~K}$.

Argon purified gas were used to degas the melt after the dispersion of ceramic particles.

Cylindrical samples, $30 \mathrm{~mm}$ in diameter and $180 \mathrm{~mm}$ in length, were casted in iron and copper moulds from the mol ten composite. 
Rapidly solidified composites were prepared by melt. spinning unit which includes a rotating copper disc.

More complete description of composite preparation tec hnique are given elsewhere [5].

The microstructure of cast composites were examined by optical and scanning electron microscopes. Keller's reagent were used for etching the samples. LEco Testing Machine (M4006 Hardness Tester). Using Vickers diamond pyramid indenter were used to measure the microhardness of the samples

\section{RESULTS AND DISCUSSIONS}

The presence of ceramic particles in aluminium melts affects the solidification microstructures compared to the basic alloy (Figs.1-3).

Experiments using various cooling rates show that pri mary cell size is slightly smaller in AlsilzCuNiMg composite compared with the basic alloy without any reinforcement ( Tab. I ).

The microstructure of rapidly solidified composites at casting in copper static mould and of melt spun-ribbon re vealed that more fine dendrite or cells are achieved and this alloys fewer ceramic particulates to be segregated in the intercellular and interdendritic boundaries, thereby giving a more homogeneous particle distribution because of the reduced time the composite is in a molten state.

Rapidly solidified structures give therefore the best ceramic particles distribution due to finer dendrite size (see Figures 3 a, 3 b).

It can be also inferred from the above results that dispersion of ceramic particles delays the extraction of heat from the matrix, due to lower thermal conductivity of the composite:

$$
\lambda_{\text {eff }}=\frac{2 \lambda_{L}+\lambda_{p}-2 \theta\left(\lambda_{L}-\lambda_{P}\right)}{2 \lambda_{L}+\lambda_{p}+\theta\left(\lambda_{L}-\lambda_{p}\right)}
$$

were $\theta$ is the volume fraction of particles.

The microhardness of the matrix of Alsil2CuNiMg/SiC, $15 \%$ vol. composite, increasing of cooling rate (Fig.4).

Increasing of microhardness could be attributed to the morphological changes in the eutectic silicon particles of the matrix, at different cooling rates.

The calculated data of $\lambda$ eff are: for Gr = 10s. 2; Sic : $90.8 ; A 1203: 6.9 ;$ TiC .. 96.9 .

\section{CONCLUSIONS}

1. The presence of ceramic particles (i.e. Graphite, SiC, Al203, TiC) in aluminium melts affects the solidification microstructures compared with the base alloy.

2. Primary cell size ls slightly smaller in $11 \mathrm{si} 12 \mathrm{CuNiMg}$ 
$15 \%$ vol. ceramic particles composite compared with the base alloy without any reinforcement

3. Much finer dendrite or cells are achieved in samples cast in copper static mould and in rapidly solidified composite by melt spinning unit and this alloys fewer cera * mic particles to be segregated in the intercellular and in terdendritic boundaries.

4. Increasing in the microhardness of the samples with increasing in cooling rate could be attributed to the morfphological changes into the eutectic silicon particles of the matrix.

\section{REFERENCES}

1. ROHATGI, P.K., ASHTANA, R., YARANDI, F. Solidif . of MMC, the Minerals, Metals and Mat.Soc., Warrendale, Pensylvania(1990) 51-75;

2. DAS, S., PRASAD, S.V., RAMACHANDRAN, T.R., ROHATGI, P.K., Mat . Trans.JIM 32 (1991) 189-194;

3. MOLDOVAN P., ALEXANDRU C., POPESCU G., GHICA G.V., I MEC VI, The Dead Sea, Israel (1993);

4.SUERY M., LAJOYE L. Solidif of MMC, The Minerals, Metals and Mat. Soc. Warrendale, Pensylvania (1990) 171-179.

5. MOLDOVAN P., POPESCU G., ALEXANDRU C., GHICA G.V., Int . Conf . of Mat. Develop. in Rail, Tire, Wing, Hull, Transp., Genoa, It aly (EUROMAT 92), 9(1992) 22-24.

TABEL. I. Cell size values of AISi $12 \mathrm{CuNiMg} / \mathrm{Cp}$ composites

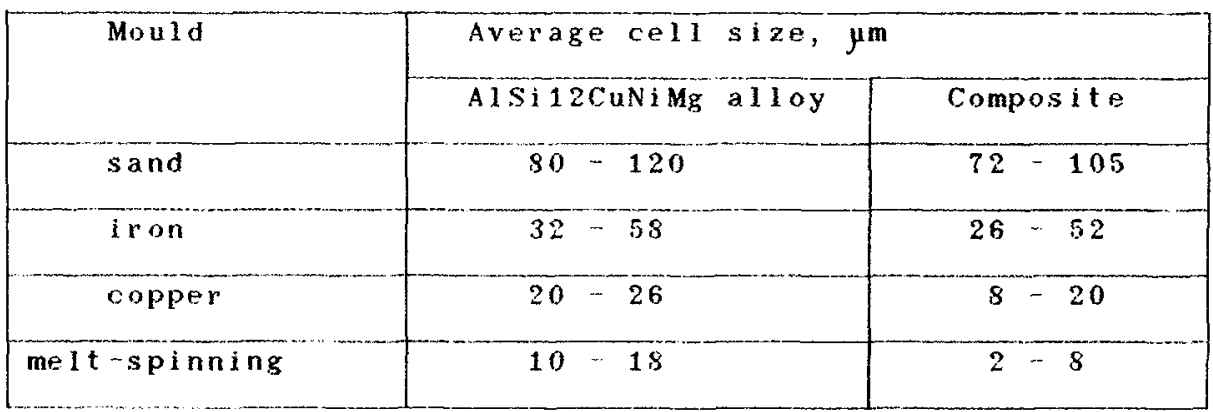




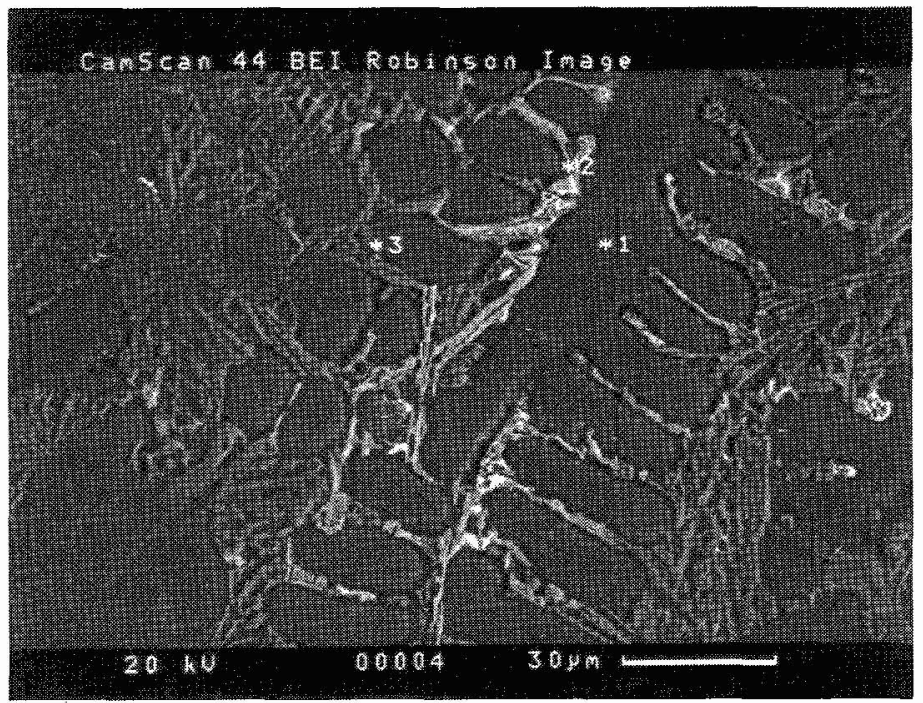

Fig.1. SEM of AlSi $12 \mathrm{CuNiMg}$ alloy.

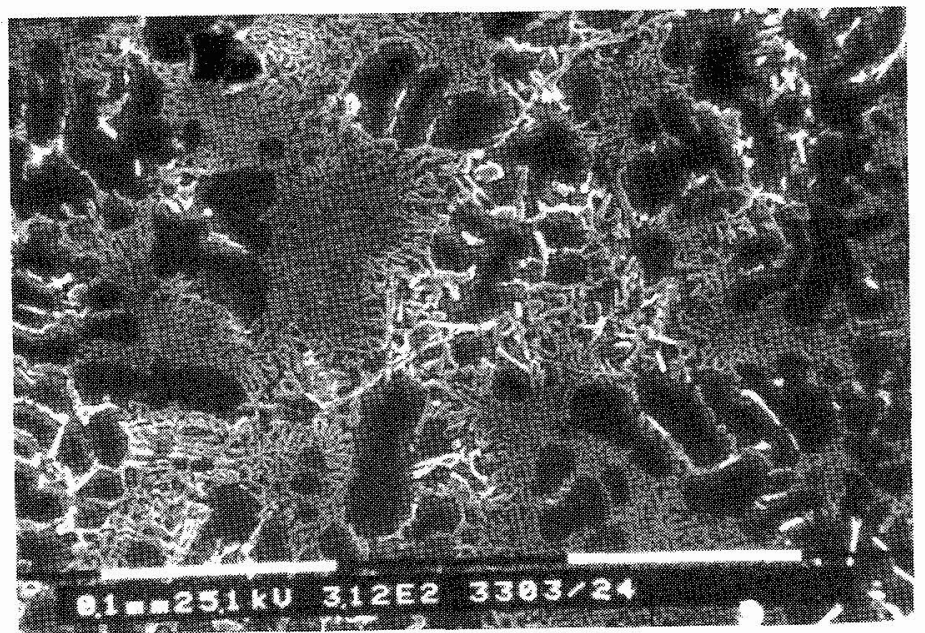

Fig. 2. SEM of AlSi $12 \mathrm{CuNiMg} / \mathrm{Gr}$ cast in copper mould. 


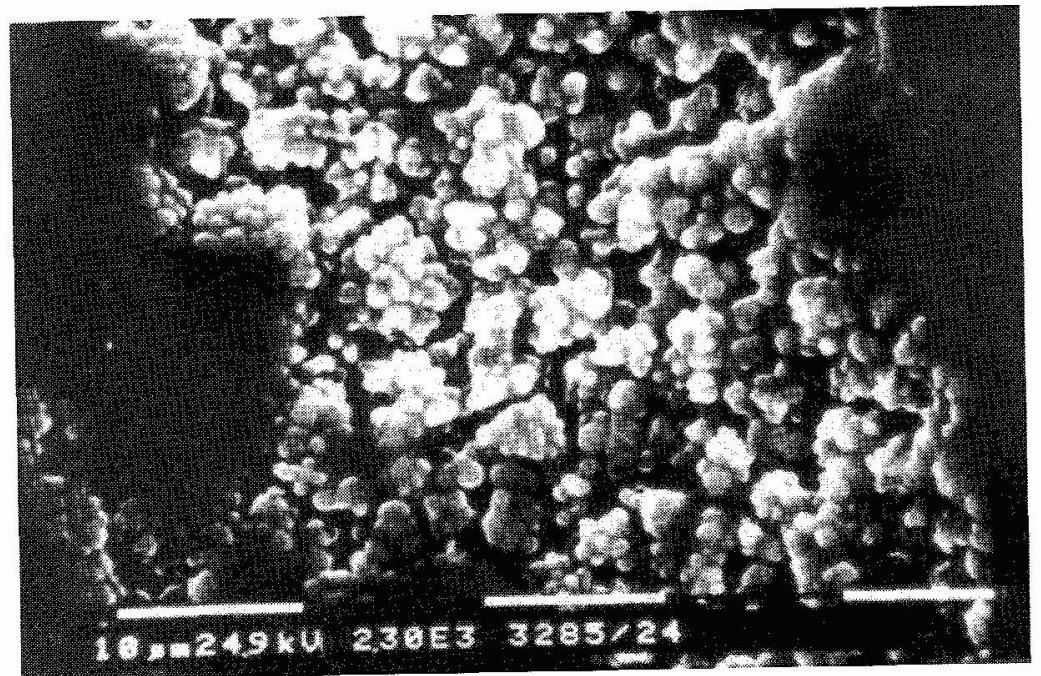

a)

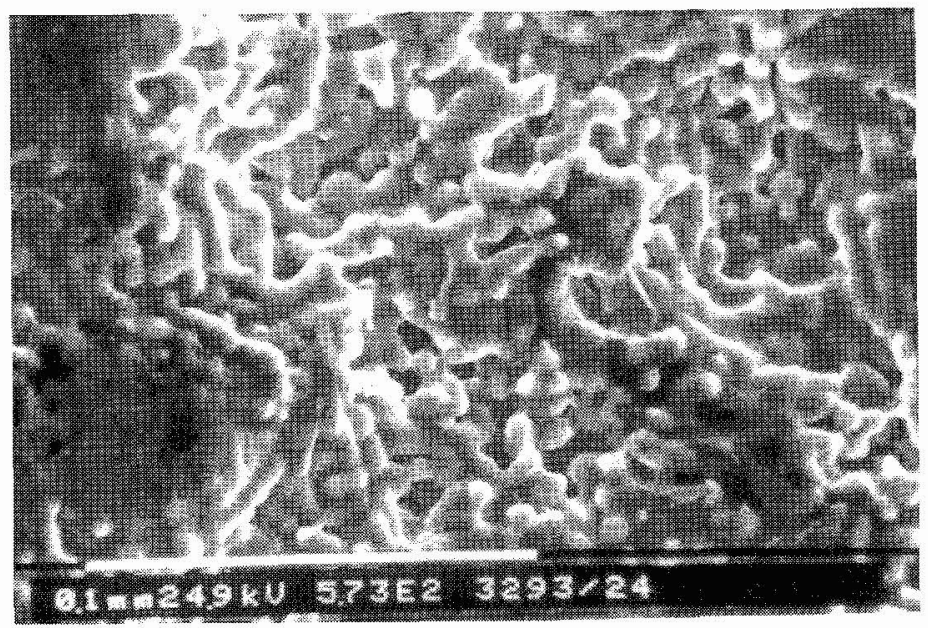

b)

Fig.3 a,b.Rapidly solidified structures of AlSi12CuNiMg with TiC composite. 


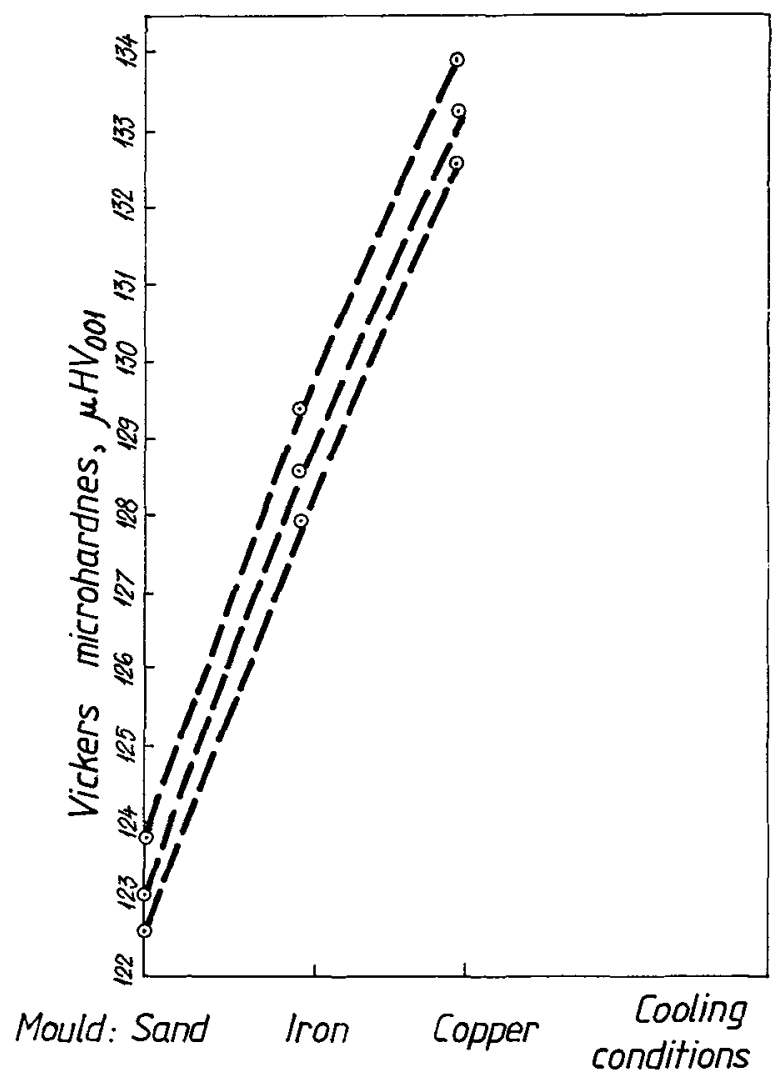

Fig. 4. The vickers microhardness of the matrix of AISi 12CuNiMg/SiCP, $15 \%$ vol. composite 